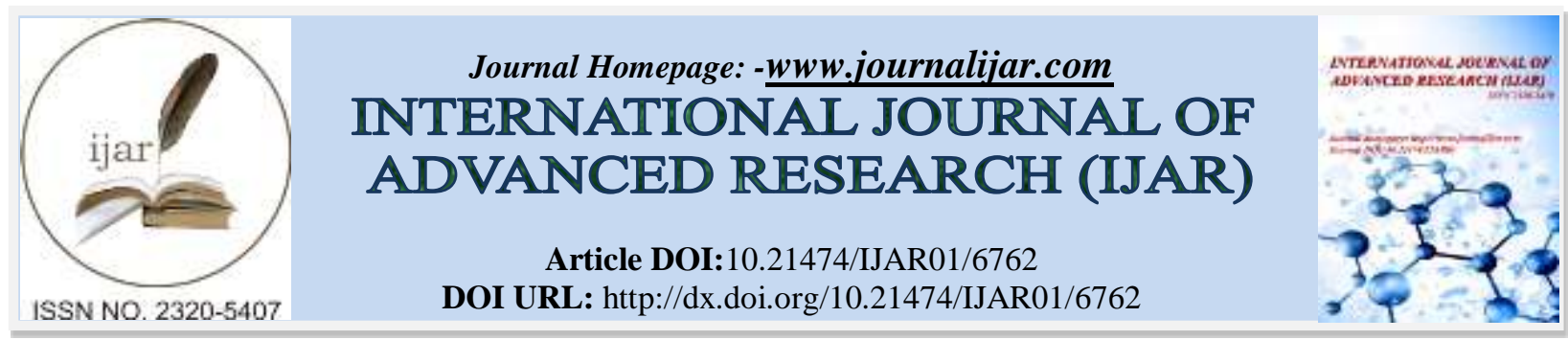

RESEARCH ARTICLE

\title{
YIELD AND FORAGE QUALITY OF ELEPHANT GRASS IN RESPONSE TO CUTTING INTERVALS.
}

Adriani Darmawati and Endang Dwi Purbajanti.

Faculty of Animal and Agricultural Sciences, Diponegoro University, Semarang, Indonesia.

\section{Manuscript Info}

-.........................

Manuscript History

Received: 16 January 2018

Final Accepted: 18 February 2018

Published: March 2018

Keywords:-

Elephant Grass, Year, Tiller Number,

Crude Protein, Crude Fiber

\section{Abstract}

The aim of the study was to identify the shorter cutting intervals in relation to the production and quality of forage. Treatments consisted of two forages cutting frequencies: 12 and 8 cutting frequencies per year ${ }^{1}$ (4 week cutting interval and 6 weeks cutting interval), at regularly spaced intervals. All treatments were replicated five times and arranged in a factorial design based on randomized complete block design. The parameters observed were tiller number, crop growth rate(CGR), biomass yields, forage production, dry matter yield (DMY), dry matter(DM) content, crude protein and crude fiber. The study showed that the tiller number at the CI 4 weeks was higher than CI 6 weeks. The CGR at 4 weekcutting interval $(43.67 \%)$ was higher $(\mathrm{p}<0.05)$ than 6 week cutting interval. The highest result of biomass yields per plot $(198.96 \mathrm{~kg})$ was gained at cutting interval 4 weeks in the second year which was significantly different in all treatments. The crude protein rate at 4 week cutting interval was higher $(13.8 \%)$ than the protein level at 6 week cutting interval. The crude fiber content at 4 week cutting interval $(28.6 \%)$ was lower than at 6 week cutting interval $(34.6 \%)$. Finally the research also showed that the 4 week cutting interval provided better nutritional quality, as reflected in the increasing levels of $\mathrm{CP}$ and the decreasing $\mathrm{CF}$, with a steady DM.

Copy Right, IJAR, 2018,. All rights reserved.

\section{Introduction:-}

Livestock production is one of the most important activities in Indonesia, and grasslands are the main feed source for Indonesian cattle herds. This results in lower production costs than that in intensive or semi-intensive systems, where animals are restricted and are fed with grains. In Indonesia, for example in Central Java, livestock production today almost exclusively requires elephant grass.

Elephant grass is a source of feed for most ruminants and is found out to be one of the most preferred types of grass favored by livestock. However, its production varies in the rainy season and in the dry season (the seasonal variation in Indonesia is indicated by the difference in rainfall mean, for example, in the months Schmidt and Ferguson called 'dry months' the rainfall mean is less than $60 \mathrm{~mm}$, while in the wet months called wet months, it is over $100 \mathrm{~mm}$ ). This is a problem since to get sustainable livestock production, the constant availability of qualified feed and forage resources are badly needed. 
Elephant Grass, also known as Napier grass or Uganda grass, is one of the most important tropical forage crops. It is widely used in cut and carry feeding systems and is of growing importance in other agricultural systems. Napier grass possesses many desirable characteristics, including high yield per unit area, tolerance to intermittent drought and high water use efficiency, making it a forage of choice. It has the ability to withstand repeated cutting and will regenerate, producing palatable leafy shoots. Enhancing the knowledge-based use and conservation of the available Napier grass resources promises to benefit livestock value chains (Negawo et al, 2017).

The success of grassland management practices should be based on thorough observation, which include morphological developments and plant physiological reactions. Both changes have proved to affect the production and quality of feed plants (Waller et al.2004). So far, such research on the productivity and quality of elephant grass has been conducted. The researchers have come up with different recommendations in determining the exact time of defoliation to get optimum production. Based on the age of the plant, Moran (2005), for example, said that elephant grass could harvest at 25 - 30 days in the rainy season or 50 - 60 days in the dry season, whereas Mwebce (2002) recommended that defoliation of elephant grass be conducted at 8 to 12 weeks.

In Indonesia, the habit of harvesting forage is 6 weeks which is the best time for plants to grow back and have the good chemical. Based on the location of the research, which is the land with high rainfall, this study was meant to find out the shorter cutting interval of forage in relation to its production and quality.

\section{Materials and Methods:- Experimental Site:-}

The research was done in Getasan region which constitutes the upland area of Tuntang watershed. The elevation of the research location is $600-1,000 \mathrm{~m}$ above sea level. In the upland area, there are many kinds of agroforestry systems. The research was conducted from December 2012 to December 2014. Getasan district has a cool climate with rainfall that adequately makes the soil fertile. Such climate includes in B2 type with its characters that has 7-9 wet months in succession and 3-4 dry months.

A composite soil sample was collected previously to the experimental setting presenting the following values for the selected properties: total organic $\mathrm{C}=1.11 \mathrm{~g} \mathrm{~kg}^{-1} ; \mathrm{pH}(1: 5$, soil:water $)=5.4 ; \mathrm{Ca}=0.7 \mathrm{cmol}^{-\mathrm{dm}^{-3}} ; \mathrm{Mg}=0.7 \mathrm{cmol}^{-\mathrm{dm}^{-}}$ ${ }^{3} ; \mathrm{K}=0.15 \mathrm{cmol} \mathrm{dm}^{-3}$; bulk density $=1.1 \mathrm{mg} \mathrm{m}^{-3}$. The area was Oxisol, the texture was loam. The amount of rainfall in 2013 was $2718 \mathrm{~mm}$ with 99 rainy days. In 2014, the amount of rainfall was $2571 \mathrm{~mm}$ with 102 rainy days. The experimental area was relatively undulating.

\section{Establishment of elephant grass:-}

The investigation was carried out from December 2012 to December 2014. The treatments consisted of two forages cutting frequencies: 12 and 8 cutting frequencies each year (4 week cutting interval and 6 week cutting interval), at regularly spaced intervals. All treatments were replicated five times and arranged in a factorial design based on randomized complete block design. Plots were $5 \mathrm{~m} \mathrm{x} 5 \mathrm{~m}$ and included 25 plants each. Plants from treatments 4 weeks CI were first pruned in January 2013 and 6 weeks were cut in the middle of February 2013, respectively, at $10 \mathrm{~cm}$ heights from the soil. This area was sown at the same spacing and time and received the same fertilizer doses as applied to the elephant grass. Cow manure $\left(2\right.$ tons.ha $\left.^{-1}\right)$ was added and incorporated $(0-20 \mathrm{~cm})$ in the soil of this area every 3 months.

\section{Soil physical and chemical properties:-}

One composite soil sample from five sampling points was taken from each plot at $0-20 \mathrm{~cm}$ depths in November 2014. Three composite samples were also taken from the elephant field to contrast their soil properties with those from the plots under study.

A portion of each soil sample was air-dried and sieved through $4 \mathrm{~mm}$ sieve for physical analyses, and $2 \mathrm{~mm}$ sieve for chemical analyses. Soil $\mathrm{N}$ was determined using the Kjeldahl method. Total organic carbon (TOC) was quantified according to a Walkey and Black methods.

\section{Measurements:-}

The Napier grass sample was taken with $5 \times 5 \mathrm{~m} 2$ plot. For fresh forage yield $\left(\right.$ t.ha $\left.^{-1}\right)$, manual harvesting with a sickle was done at a respective time of harvest for each treatment (4 weeks and 6 weeks), respectively, and the 
bundles were then weighed immediately. The dry matter was obtained by baking 50 gr of forage sample in an oven at $105^{\circ} \mathrm{C}$ for 24 hours. The content of crude protein was measured by the Kjeldahl method, while the content of crude fiber was measured by dissolving it using strong acid (AOAC, 2005). The crop growth rate and production of dry matter were measured according to the content of dry matter and its fresh produce, such as: one composite soil sample from five sampling points was taken from each plot at 0-20 cm depths in November 2014. Three composite samples were also taken from the elephant grass field to contrast their soil properties with those from the plots under study.

$$
\begin{gathered}
\text { Crop growth rate }=\frac{\text { Dry weight in harvest time-dry weight stek }}{\text { Time of harvest-time of planting }} \times 100 \% \\
\text { Dry matter percentage }=\frac{\text { Dry weight }}{\text { Fresh weight }} \times 100 \%
\end{gathered}
$$

Dry matter production $\left(D M P, t^{-h} a^{-1}\right)=$ Fresh Weight Production x Dry Weight Content

The crude protein content was measured based on the nitrogen content which was measured using Kjeldahl method, with the calculation as follows: Crude protein content $=\mathrm{N} \times 6,25$

\section{Statistical Method:-}

All data collected were then tested on ANOVA (analysed of varians) based, and to determine the difference among treatments, Duncan's Multiple Range Test (DMRT) was done by referring to Steel and Torrie (1980).

\section{Results And Discussion:- Soil Properties:-}

The ANOVA results show that cutting intervals and different years did not show any interactions. Years show different effects on soil $\mathrm{N}$ content. The $\mathrm{N}$ content of soil in the second year was $58.6 \%$ higher than the $\mathrm{N}$ soil in the first year (Table 1). ANOVA results show that cutting intervals and different years did not show interaction, a year or type of cutting interval did not show a different effect on soil $\mathrm{pH}$ content. The ANOVA results show that cutting intervals and different years did not show interaction. The year and the type of cutting intervals did not show any different effects on the $\mathrm{C}$ organic content of the soil. The ANOVA results show that cutting interval and different year did not show interaction. Year or type of cutting interval did not show a different effect on soil bulk density content.

\begin{tabular}{|c|c|c|c|c|}
\hline Year & $\mathrm{N}$ soil $(\%)$ & $\mathrm{pH}$ & C organic $(\%)$ & $\begin{array}{l}\text { Bulk density } \\
\left(\mathrm{g} / \mathrm{cm}^{-3}\right)\end{array}$ \\
\hline \multicolumn{5}{|l|}{2013} \\
\hline \multicolumn{5}{|l|}{ Cutting interval (CI) } \\
\hline 4 weeks & $0.30 \mathrm{~b}$ & $5.32 a$ & $1.48 \mathrm{a}$ & $1.14 \mathrm{a}$ \\
\hline 6 weeks & $0.29 \mathrm{~b}$ & $5.66 \mathrm{a}$ & $1.50 \mathrm{a}$ & $1.10 \mathrm{a}$ \\
\hline \multicolumn{5}{|l|}{2014} \\
\hline \multicolumn{5}{|l|}{ Cutting interval (CI): } \\
\hline 4 weeks & $0.50 \mathrm{a}$ & $5.50 \mathrm{a}$ & $1.94 \mathrm{a}$ & $1.12 \mathrm{a}$ \\
\hline 6 weeks & $0.43 \mathrm{ab}$ & $5.62 \mathrm{a}$ & $2.12 \mathrm{a}$ & $1.14 \mathrm{a}$ \\
\hline Years : 2013 & $0.29 b$ & $5.49 \mathrm{a}$ & $1.49 \mathrm{a}$ & $1.12 \mathrm{a}$ \\
\hline 2014 & $0.46 \mathrm{a}$ & $5.56 \mathrm{a}$ & $2.03 \mathrm{a}$ & $1.13 \mathrm{a}$ \\
\hline \multicolumn{5}{|l|}{ Cutting interval (CI): } \\
\hline 4 weeks & $0.396 \mathrm{a}$ & $5.41 \mathrm{a}$ & $1.71 \mathrm{a}$ & $1.13 \mathrm{a}$ \\
\hline 6 weeks & $0.358 \mathrm{a}$ & $5.64 \mathrm{a}$ & $1.81 \mathrm{a}$ & $1.12 \mathrm{a}$ \\
\hline \multicolumn{5}{|l|}{ Fvalue } \\
\hline & $\mathrm{N}$ soil & $\mathrm{pH}$ & C organic & Bulk density \\
\hline Year (Y) & $12.00 *$ & $0.25 \mathrm{~ns}$ & $3.96 \mathrm{~ns}$ & $0.22 \mathrm{~ns}$ \\
\hline Cutting interval (CI) & $0.60 \mathrm{~ns}$ & $2.75 \mathrm{~ns}$ & $0.14 \mathrm{~ns}$ & $0.22 \mathrm{~ns}$ \\
\hline
\end{tabular}

Table 1:- Soil properties of study sites at different cutting intervals and years 


\begin{tabular}{|l|l|l|l|l|}
\hline $\mathrm{Y}^{*} \mathrm{CI}$ & $0.37 \mathrm{~ns}$ & $0.63 \mathrm{~ns}$ & $0.09 \mathrm{~ns}$ & $2.00 \mathrm{~ns}$ \\
\hline
\end{tabular}

\section{Growth and Yield of Elephant Grass:-}

Tiller number:-

ANOVA results show that the interaction between the year and cutting interval had no effect on tiller number elephant grass. Year factor and cutting interval each had a real effect on tiller number (Table 2). Tiller number at the CI 4 weeks was higher than CI 6 weeks. The interaction between cutting intervals and year factor shows a significant effect on CGR of Elephant grass. Year factor and cutting intervals each had a significant effect on CGR of Elephant grass. CGR in the second year was $43.4 \%$ real $(\mathrm{p}<0.05)$ higher than in the first year. CGR at cutting interval 4 weeks $(43.67 \%)$ was higher $(\mathrm{p}<0.05)$ than cutting interval 6 weeks.

The interaction between cutting intervals and year factor shows a significant effect on biomass yield per plot of Elephant grass. Year factor and cutting interval each had a real effect on biomass yield per Plot of Elephant grass. The highest biomass yield per plot (198.96 kg. plot-1) was at cutting interval 4 weeks in the second year which was significantly different in all treatments. Compared to the first year, CI 4 weeks in the second year increased by $67 \%$. Biomass resulted in CI 4 weeks of the second year, when compared with 6 weeks in the second year, it was $84.7 \%$ higher. The interaction between cutting intervals and year factor shows a significant effect on forages production of Elephant grass.

Year factor and cutting interval each had a real effect on forages production of Elephant grass. The highest result of Forages production (517.29 tons.ha-1) was at cutting interval 4 weeks in the second year which was significantly different in all treatments. Compared to the first year, Forage production at CI 4 weeks in the second year increased by $67.0 \%$. The interaction between cutting intervals and showing a significant effect on Dry Matter Production of Elephant grass. Year factor and cutting interval each had a real effect on Dry Matter Production of Elephant grass. The highest result of Forages production per plot (198.96 kg.plot-1) was at cutting interval 4 weeks in the second year which was significantly different in all treatments. Compared to the first year, DM production in CI 4 weeks in the second year increased by $104.9 \%$.

Table 2:- Growth, production and chemical composition of elephant grass due to cutting intervals and length of different management

\begin{tabular}{|c|c|c|c|c|c|c|c|c|}
\hline Year & Tilllering & $\begin{array}{l}\text { CGR } \\
\left(\text { g.day }^{-1}\right)\end{array}$ & $\begin{array}{l}\text { Biomass } \\
\mathrm{kg} / \text { plot }\end{array}$ & $\begin{array}{l}\text { Forage } \\
\text { production } \\
\text { t/ha }\end{array}$ & $\begin{array}{l}\text { DMY } \\
\text { t/ha }\end{array}$ & $\begin{array}{l}\mathrm{DM} \\
(\%)\end{array}$ & $\begin{array}{l}\mathrm{CP} \\
(\%)\end{array}$ & $\begin{array}{l}\text { CF } \\
(\%)\end{array}$ \\
\hline \multicolumn{9}{|l|}{2013} \\
\hline 4 weeks & $22.53 \mathrm{a}$ & $161.80 \mathrm{~b}$ & $119.14 \mathrm{~b}$ & $309.75 \mathrm{~b}$ & $60.39 \mathrm{~b}$ & $19.02 \mathrm{a}$ & $7.72 \mathrm{a}$ & $27.40 \mathrm{a}$ \\
\hline 6 weeks & $26.23 \mathrm{a}$ & $95.70 \mathrm{c}$ & $105.90 \mathrm{~b}$ & $183.56 \mathrm{c}$ & $32.12 \mathrm{c}$ & $16.94 a$ & $6.66 \mathrm{a}$ & $32.80 \mathrm{a}$ \\
\hline \multicolumn{9}{|l|}{2014} \\
\hline 4 weeks & $28.75 \mathrm{a}$ & $271.88 \mathrm{a}$ & $198.96 \mathrm{a}$ & $517.29 \mathrm{a}$ & $123.72 \mathrm{a}$ & $23.92 \mathrm{a}$ & $7.44 \mathrm{a}$ & $29.88 \mathrm{a}$ \\
\hline 6 weeks & $20.01 \mathrm{a}$ & $97.36 \mathrm{c}$ & $107.72 \mathrm{~b}$ & $186.71 \mathrm{c}$ & $40.46 \mathrm{c}$ & $21.71 \mathrm{a}$ & $6.66 \mathrm{a}$ & $36.48 \mathrm{a}$ \\
\hline \multicolumn{9}{|l|}{ Years } \\
\hline 2013 & $22.5 \mathrm{~b}$ & $128.75 b$ & $112.52 \mathrm{~b}$ & $246.70 \mathrm{~b}$ & $46.26 \mathrm{~b}$ & $17.98 \mathrm{~b}$ & $7.19 a$ & $30.10 \mathrm{~b}$ \\
\hline 2014 & $26.2 \mathrm{a}$ & $184.62 \mathrm{a}$ & $153.34 \mathrm{a}$ & $352.00 \mathrm{a}$ & $82.09 \mathrm{a}$ & $22.82 \mathrm{a}$ & $7.05 \mathrm{a}$ & $33.18 \mathrm{a}$ \\
\hline \multicolumn{9}{|l|}{$\begin{array}{l}\text { Cutting } \\
\text { Interval }\end{array}$} \\
\hline 4 weeks & $28.75 \mathrm{a}$ & $216.84 a$ & $159.05 \mathrm{a}$ & $413.52 \mathrm{a}$ & $92.06 \mathrm{a}$ & $21.47 \mathrm{a}$ & $7.58 \mathrm{a}$ & $28.64 \mathrm{~b}$ \\
\hline 6 weeks & $20.01 b$ & $96.53 b$ & $106.81 \mathrm{~b}$ & $185.14 \mathrm{~b}$ & $36.29 \mathrm{~b}$ & $19.33 \mathrm{a}$ & $6.66 \mathrm{~b}$ & $34.64 \mathrm{a}$ \\
\hline \multicolumn{9}{|c|}{ F value } \\
\hline & Tilllering & CGR & $\begin{array}{l}\text { Biomass } \\
\text { Kg/plot }\end{array}$ & $\begin{array}{l}\text { Fresh yield } \\
\text { t/ha }\end{array}$ & $\begin{array}{l}\text { DMY } \\
\text { t/ha }\end{array}$ & DM & $\mathrm{CP}$ & $\mathrm{CF}$ \\
\hline Year $(\mathrm{Y})$ & $8.86^{*}$ & $44.7^{*}$ & $34.86^{*}$ & 41.39* & $36.12 *$ & $11.55^{*}$ & $0.22 \mathrm{~ns}$ & $74.52^{*}$ \\
\hline $\begin{array}{l}\text { Cutting } \\
\text { interval(CI) }\end{array}$ & $49.44^{*}$ & $205.28^{*}$ & $57.09 *$ & 194.52* & $87.51^{*}$ & $2.27 \mathrm{~ns}$ & $9.67 *$ & $282.80^{*}$ \\
\hline $\mathrm{Y} * \mathrm{CI}$ & $1.50 \mathrm{~ns}$ & $41.68 *$ & $31.82 *$ & $38.95 *$ & $21.28^{*}$ & $0.001 \mathrm{~ns}$ & $0.22 \mathrm{~ns}$ & $2.83 \mathrm{~ns}$ \\
\hline
\end{tabular}




\section{Chemical Composition of Elephant Grass:-}

ANOVA results show that the interaction between year and cutting interval had no effect on DM elephant grass. Year shows a real influence on DM. DM content in the second real year $(p<0.05)$ was higher $(26.92 \%)$ than in the first year. ANOVA results show that cutting intervals and different years did not show interactions in crude protein. Factor years showed no different effects on crude protein. This cutting interval shows different effects on a crude protein of Elephant grass. The crude protein rate at cutting interval 4 weeks was higher (13.8\%) than the protein level at the cutting interval of 6 weeks. ANOVA results show that cutting intervals and different years did not show interactions in crude fibers. Year factor shows different effects on crude fibers. This cutting interval shows different effects on crude fibers of Elephant grass. The crude fibers content was higher $(p<0.05)$ in the second year than in the first year. Levels of CF at cutting interval 6 weeks was higher than cutting 4 weeks. Crude fiber content at 4 weeks cutting interval (28.6\%) was lower than 6 weeks cutting interval (34.6\%).

Rainfall

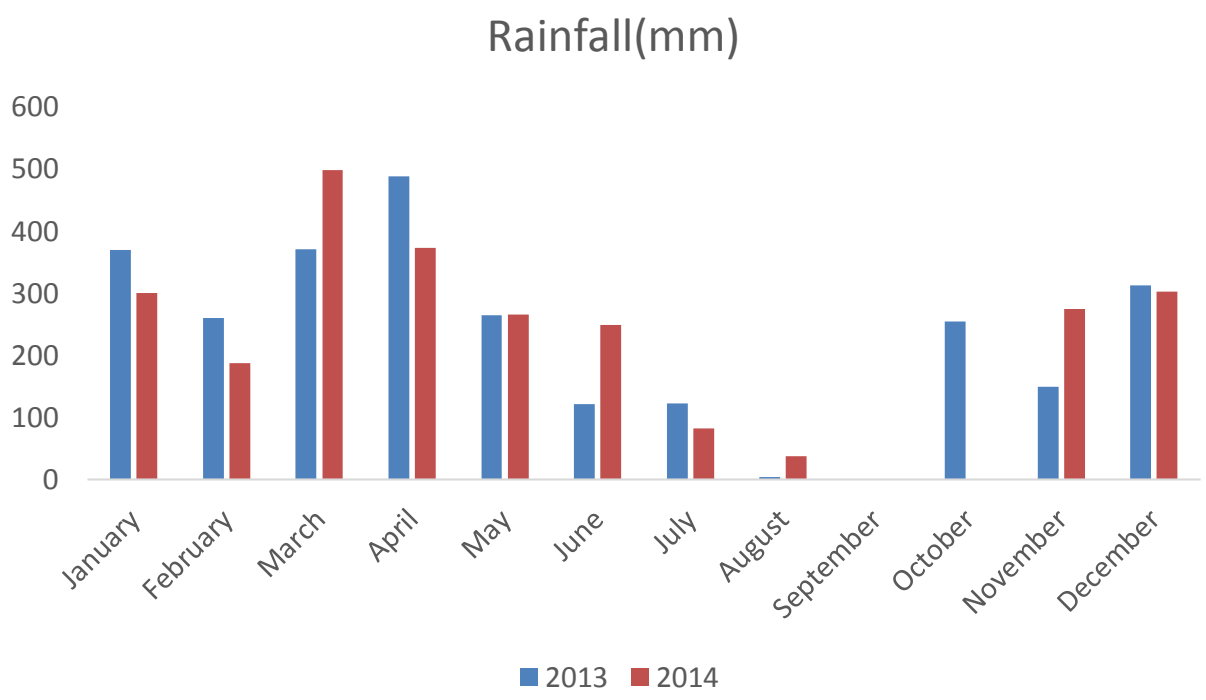

Discussion:-

Soil Properties:-

In the research it was found out that the soil $\mathrm{N}$ increased compared to that in the first year. It was probably derived from the additional manure that had not been completely shrunken in the first year and finally added to the soil $\mathrm{N}$ in the second year. The $\mathrm{C}$ org, $\mathrm{pH}$, and bulk density were not real. It was possibly due to the fact that the physical properties of the soil could not affect the change of the specific gravity. Meanwhile, although the organic $\mathrm{C}$ had not been real, it tended to increase in the second year (10\% test).

According to Hatfield et al. (2007), changes in bulk density and soil nutrient profile are the concerns of crop producers. Changes in bulk density and nutrients happen in soil profiles which experience inconsistent treatment and sheep way in eating the rest of wheat crop. This shows the potential that allows sheep to graze on wheat straw without damaging and affecting the bulk density of soil or soil profile. Dubeux Jr et al. (2006) added that soil organic matter (SOM) affects soil physical, chemical, and biological properties, and is an important indicator of ecosystem sustainability. Sustainable land management should include practices that elevate, or at least maintain, the appropriate SOM for the given soil. Based on this single criterion, well-managed pastures are sustainable production systems because SOM has observed to increase. Because $\mathrm{C}$ inputs in productive pastures increase compared to low input systems, it is expected that SOM increases more in managed paste systems.

The research location had a rainfall of $2718 \mathrm{~mm}$, with rainy days of 99 in 2013 and $2571 \mathrm{~mm}$ with rainy days of 102 in 2014. In 2013, the months of December to July were wet months (rainfall> $100 \mathrm{~mm}$ according to Schmidt and Ferguson, while months of August to September, from December to June were wet months (rainfall> $100 \mathrm{~mm}$ according to Schmidt and Ferguson, while dry months July to October) Based on falling rainfall, the study area is a sufficient area of water. 


\section{Growth and Production:-}

The ability of elephant grass to grow was related to its capacity to cover the soil and thereby prevented the entry of weeds that have caused grassland degradation. Elephant grass was able to form saplings. This clonal reproduction nwas one of the most efficient mechanisms to ensure a persistence of elephant grass. In addition, persistence of elephant grass was caused by high tolerance to defoliation, because it had abundant growth rate and is well protected. The strength of growing elephant grass was also supported by the distribution of rainfall throughout the year so that its production was high. The average yield of higher livestock feeds got in 2014 compared to 2013 was due to the ability to grow and persistence of elephant grass that had been good during the second year.

Factors that affected the number of tillers were the availability of water, nutrition, and sunlight, planting season, and the ability of plants to respond to varied environments. If the number of tillers per unit area increased, then the number of plants per unit area would increase. This resulted in the increasing density of plant so that it was predicted that DM yield would also increase.

The better growth phase of the plant and creation of an optimal microenvironment through leaf defoliation expected to be photosynthesis and assimilate translocation was optimal. As a matter of fact, plant growth is a process of plant life from various physiological processes, involving genotypes and environmental factors interacting with each other. The growth process involve sincreasing size, shape and quantity over time. A plant can grow and develop if all the needs of the plant can be fulfilled to the fullest. Efforts can be made to increase the elephant grass production by leaf defoliation at certain positions and ages to balance between vegetative and generative plant growth patterns, besides the defoliated leaves that can obtain forages. Defoliation alters the microclimate of plant environments, where reduced canopy crops will be followed by increased light penetration, resulting in rising ground surface temperatures, which stimulate the growth of saplings from the crown part of the grass plant. The section as one of the storage reserves of energy for regrowth (Ansah et al, 2010). The ability of forages to regenerate after defoliation is due to sufficient growth and reserve energy (Wijitphan et al., 2009).

The data also show that $B$. humidicola grasses other than persistent to recurrent defoliations could also produce new chicks that were usually more vigorous and of higher quality after defoliation. As a result of cutting intervals, even though the leaf dry weight was smaller because it wasa deficit, the dry weight of the roots was even greater. This phenomenon described the ability of elephant grass to survive even though it was de-defoliated. In this case defoliation stimulated the root component to develop so that in turn it was able to provide nutrients for the regrowth of the grass plants (Wang et al., 2003). DM yield variation in elephant grass was influenced by climatic factors factor, soil water availability, nutrients availability, plant density, harvest time and method. The yield of DM yield had reached 123.72 tons per year ${ }^{-1}$ with 30 days cutting interval greater than Negawo et al., (2017) research result of 78 tons. ha ${ }^{-1}$. Year ${ }^{-1}$ with regular cutting between 60 to 90 days. The accumulated dry biomass ranged from 30 to 42 $\mathrm{Mg} \mathrm{ha}^{-1}$ with 180 days cuts (Flores et al., 2012).

\section{Quality:-}

The DM contained in the grass changed with the age of the plant, the older plant got less water content and the proportion of cell walls was higher than the contents of the cell (If the cell wall content of the plant is larger, the plant will contain more DM). The value of this dry matter content was also affected by the defoliation interval because defoliation affects grass production. In fact ,keeping the plants young to obtain high nutritional value by adjusting short defoliation intervals can lead to a decrease in the production of dry forage.

During the research, the protein content (\%) was determined by using Kjeldahl Method (AOAC, 2005). Crude fiber (\%) was also determined by following the official method of Analysis (AOAC, 1990). At CI 4 weeks, as the age of the plant was still young, the elephant grass looked more green and young, showing that the protein produced was also highest. Indeed, age affects the crude fiber content of plants. The older the plants were, the more crude fiber content can be gained. Table 2 above shows that longer cutting intervals decreased the crude protein content. This is due to the fact that in older plants there is higher crude fiber content and lower levels of protein. The more ages the plants had, the larger the cells grew. The cell wall thickened and the development of wood vessels was expanded so that the production of dry matter increased, but the nutritional content decreased. The decline in nutritional value in the last year of the evaluation (in 2014), both in terms of DMD and CP was also observed through the increasing value of crude fiber associated with low-quality feed due to the anti-nutrient lignin in cellulose. This increase in CF may associate with higher proportion of stems in the harvested feed and leaf reduction. This is in line with Churkova (2013) who stated that lower crude fiber content of the forage was an indicator of its better quality. The chemical 
composition and nutritive value of the forage varied depending on the botanical composition, the phase of growing season, fertilization, and the growing conditions. As water content and the content of crude protein decreased, vegetation, and crude fibers increased. Crude protein in this study differs from the results of Onyeonagu and Eze, (2013), which was $16.66 \%$ in the rainy season and $9.62 \%$ in the dry season, while crude fibers were $11.27 \%$ in the rainy season and $18.0 \%$ in the dry season. Okaraonye and Ikewuchi (2009) reported crude protein from Pennisetum purpureum was 27\%. Purbajanti et al (2009) reported that on saline soil crude protein of Pennisetum purpureum was $7.02 \%$, while crude fibers were $31.67 \%$. Bilbao et al (2004) reported that proteins comprised amino acids derived from nitrogen. The developed nitrogen plants also determined the quality of crops. Nitrogen was required for the vegetative growth of the plant.

During the tested periods, the CP content varied with the cutting intervals but there was no significant differences with years. The CP contents were similar in the 2013 and 2014 and the significant differences in the CI 4 weeks and CI 6 weeks. The highest average CP content was obtained in the CI 4 weeks (7.58\%) and CI 6 weeks (6.66\%). This result was probably due to favorable climatic conditions for herbage growth and development during these periods. This result was lower than Antony and Thomas was CP 10.73-14.17\% and CF 8.42-31.05\%

Churkova (2013) argued that the chemical composition and nutritional value of forage varied depending on botanical composition, planting phase, fertilization and growth conditions. As the water content and the crude protein decreased, vegetation, and crude fiber increased. The protein content was affected for the most part by soil type, and the amount and type of mineral fertilizer are applied. Crude fibers content was directly related to the amount of temperature and quantity of rainfall. Where grassland grew. The crude fiber content tended to increase with the increase of water supply to the grass plot. This explains why the crude fibers content in the first year was lower than in the following year.

\section{Conclusion:-}

In the second year, there was an improvement in the soil fertility with the increasing soil $\mathrm{N}$, whereas $\mathrm{pH}$, Bulk density, $\mathrm{C}$ organic had no effect in the two year trial. In the second year there was usually improvement of the growth and yield of the elephant grass. The chemical component of the elephant grass in the second year also experienced improvement of the DM and crude fiber content, while the PK showed no difference. The time short cutting intervals (4 weeks) provided better nutritional quality as reflected by increase of CP levels and the decrease of CF, with steady DM. Forage production was also better at the shorter cuts. Thus, the research recommended that theshorter time cut intervals of 4 weeks be better than that of 6 weeks.

\section{Acknowledgment:-}

The authors wish to acknowledge the financial support from the Faculty of Animal and Agricultural Sciences, Diponegoro University. They would also like to thank the Study Programe of Agroecotechnology, Faculty of Animal Agriculture and Animal Sciences, Diponegoro University, Semarang, Indonesia for the research facility. 


\section{References:-}

1. Ansah, T., E.L.K Osafo and H. H. Hansen.2010. Herbage yield and chemical composition of four varieties of Napier (Pennisetum purpureum) grass harvested at three different days afterPlanting. Agric. Biol. J. N. Am., 2010, 1(5): 923-929

2. Antony, S. and C. George Thomas. 2014. Nutritive quality of hybrid napier cultivars grown under rainfed ecosystem Journal of Tropical Agriculture 52 (1) : 90-93, 2014

3. Association of Official Analytical Chemist (AOAC). 2005. Official Methods of Analysis 1995-2005. AOAC, Arlington.

4. Bilbao, M., J.J. Martinez and A. Delgado, 2004. Evaluation of soil nitrate as a predictor of nitrogen requirement for sugar beet grown in a Mediterranean climate. Agron. J., 96: 18-25.

5. Churkova, B.G. 2013. Content of Crude Protein, Crude Fiber and Crude Ash in Dry Mass of Birdsfoot Trefoil Varieties and Populations. American Journal of Agricultural Science and Technology (2013) Vol. 1 No. 3 pp. 77-83.

6. Dubeux Jr. J.C.B., L.E. Sollenbergerb,_ N.B. Comerfordb, J.M. Scholbergb, A.C. Ruggieric,

7. J.M.B. Vendraminid, S.M. Interranteb, K.M. Portier. 2006. Management intensity affects density fractions of soil organic matter from grazed bahiagrass swards. Soil Biology \& Biochemistry 38 (2006) 2705-2711.

8. Flores, R.A., S. Urquiaga, B. J. R.Alves, L. S. Collier, R. M. Boddey. 2012. Yield and Quality of Elephant Grass Biomass Produced in The Cerrados Region for Bioenergy. Eng. Agríc., Jaboticabal, v.32, n.5, p.831-839, set./out. 2012.

9. Hatfield, P.G., H.B. Goosey, T.M. Spezzano, S.L. Blodgett, A.W. Lenssen, R.W. Kott and C.B. Marlow, 2007. Incorporating sheep into dryland grain production systems: III. Impact on changes in soil bulk density and soil nutrient profiles. Small Rumin. Res., 67: 222-231.

10. Moran, J. 2005. Growing quality forages. In: Tropical dairy farming : feeding management

11. for small holder dairy farmers in the humid tropics. Department of Primary Industries. http: //www.landlinks.com.au.

12. Mwebaze, S. 2002. Pasture improvement technologies based on an on-farm study in Uganda.Regional Regional Land Management Unit (RELMA). Department of Animal Productionand Marketing, MAAIF, P.O. Box 513, Entebbe Uganda

13. Negawo,A.T., A.Teshome, A. Kumar, J. Hanson and C. S. Jones ' 2017. Opportunities for Napier Grass (Pennisetum purpureum) Improvement Using Molecular Genetics. Agronomy 2017, 7(2), 28; doi:10.3390/agronomy7020028

14. Okaraonye, C.C., and J.C. Ikewuchi, 2009. Nutritional and Antinutritional Components of Pennisetum purpureum (Schumach). Pakistan Journal of Nutrition, 8: 32-34.

15. Onyeonagu, C. C. and S. M. Eze. 2013. Proximate compositions of some forage grasses and legumes as influenced by season of harvest. African Journal of Agricultural Research. Vol. 8(29), pp. 4033-4037, 1 August, 2013 .

16. Purbajanti,E.D., S Anwar, S Widyati, F Kusmiyati.2009. Crude Protein and Crude of Fiber Benggala [Panicum Maximum] and Elephant [Pennisetum purpureum] Grasses on Drought Stress Condition. Animal Production 11(2): 109-115 (2009).

17. Steel, R.G.D. and J.H. Torrie, 1980. Principles and Procedures of Statistics: A Biometric Approach. 2nd Edn., McGraw Hill Book Co., New York, USA. 633p.

18. Waller, S. S., L. E. Moser, and P. E. Reece. 2004. Basic concept of grass growth. In:

19. Understanding grass growth: The key to profitable livestock production. (Ed. G.A.

20. Gates) Trabon Printing, Co., Inc. Kansas City, Missouri.

21. Wang, R.Z., Q. Gao and Q.S. Chen. 2003. Effect of climate change on biomass and biomass and biomass allocation in Leymus chinensis (Poaceae) along the North-East China Transect (NECT). J.Arid. Environ. 54: 653-665.

22. Wijitphan, S., P. Lorwilai, C. Arkaseang. 2009. Effect of cutting heights on productivity and quality of Napier Grass under irrigation. Pakistan J. Nutr. 8(8): 1244-1250. 